$\xi^{2}=-$

\title{
Yield contributing characters of BRRI dhan49 as influenced by integrated use of banana leaves with inorganic potassium fertilizer
}

\author{
Md. Abdul Mannan 1, Md. Abul Hashem 2, Md. Sohanur Rahman ${ }^{3}$ *, \\ Fakhar Uddin Talukder ${ }^{3}$, Md. Kamrujjaman ${ }^{4}$ \\ ${ }^{1}$ Agriculture Extension Officer, Department of Agricultural Extension, Bangladesh \\ ${ }^{2}$ Department of Soil Science, Bangladesh Agricultural University, Bangladesh \\ ${ }^{3}$ Pest Management Division, Bangladesh Jute Research Institute, Bangladesh \\ ${ }^{4}$ Fiber Quality Improvement Division, Bangladesh Jute Research Institute, Bangladesh \\ *Corresponding author E-mail: sohanbau2010@gmail.com
}

\begin{abstract}
A field experiment was carried out at the Soil Science Field Laboratory of Bangladesh Agricultural University (BAU), Mymensingh during aman season of 2014 to study the integrated use of banana leaves with inorganic potassium fertilizer on the growth and yield of BRRI dhan49 following Randomized Complete Block Design (RCBD) with eight treatments and three replications. The highest plant height $(85.55 \mathrm{~cm})$, panicle length $(21.46 \mathrm{~cm})$, number of effective tillers hill-1 (11.54), number of filled grains panicle-1 (149.53), 1000grain weight $(21.85 \mathrm{gm})$, grain yields $(5.66 \mathrm{t}$ ha-1) and straw yield $(6.81 \mathrm{t} \mathrm{ha}-1)$ were obtained in the treatment $\mathrm{T} 3$ and the lowest plant height $(77.10 \mathrm{~cm})$, panicle length $(18.85 \mathrm{~cm})$, number of effective tillers hill-1 (8.64), number of filled grains panicle-1 (112.11), 1000grain weight (19.96gm), grain yields (3.50 t ha-1) and straw yield (4.73 tha-1) were recorded in the control. It can be recommended to integrated use of $50 \% \mathrm{~K}$ from banana leaves $+50 \% \mathrm{~K}$ from MoP on growth and yield of BRRI dhan 49 .
\end{abstract}

Keywords: Yield Contributing Characters; Banana Leaves; Potassium Fertilizer and BRRI Dhan49.

\section{Introduction}

Bangladesh is an agriculture based country where agriculture is the single largest sector and the mainstay of the economy. Rice is the staple food of the people of Bangladesh. It is the single most important human energy source; feed about half of the world's population.

Soil is the principal supplier of plant nutrients. Plant derives 14 essential elements of 17 from the soil. But soil varies considerably in their inherent capacities to supply nutrients which are gradually declining over time due to intensive cropping with high yielding rice varieties in Bangladesh. It has been using chemical fertilizers year after year for higher yield. Nitrogen, phosphorus and potassium are three major elements which are often applied through chemical fertilizers. As a result, our soil is losing their bearing capacity for higher yield. Most of the chemical fertilizers are imported to Bangladesh except urea only. A large amount of money is needed to buy these chemical fertilizers. Phosphorus and potassium are mainly imported from foreign counties and expense large amount of foreign currency. It is possible to obtain higher crop yield by using only organic manure.

Sustainable crop production could be possible through the integrated use of organic manures and chemical fertilizers. Nambiar (1991) indicated that integrated use of organic manures and chemical NPK fertilizers would be quite promising not only in providing greater stability in production but also in maintaining higher soil fertility status.

Potassium plays a major role in crop growth and development and dressing of potassium can alleviate the sterility problem in rice. It performs many functions in plant such as synthesis of protein and starch, promoting growth and increasing yield, increasing resistance to pests, promoting root growth, regulating water utilization by plant, strengthening plant tissues and preventing lodging. Lodging of rice plant increases sterility during flowering, which causes the unexpected yield reducing in rice. Potassium increases strength of rice stalk, and thus prevents plants from lodging and reduces sterility.

Application of higher rate of potassium increases all the growth parameters (Thakur et al., 1993). Among all the essential nutrients, potassium is absorbed in maximum amount by modern improved crop cultivars (Fageria et al., 1990).

Generally annual potassium rich crops like banana is used as green manure throughout the world. It is very common in Bangladesh and its leaves contain substantial amounts of $\mathrm{K}$ and other nutrients also. Litter of banana leaf contain $3.55 \% \mathrm{~K}$ (Shymum, 2006).

Therefore, the present investigation was undertaken to study the effect of integrated use of banana leaves with inorganic fertilizer on the yield and yield contributing characters of rice. 


\section{Materials and methods}

\subsection{Experimental site and soil}

The experiment was set up at Soil Science Field laboratory of Bangladesh Agricultural University, Mymensingh during the Aman season of 2014. The soil belongs to the sonatola series of Non-calcarieous Dark Gray Floodplain soils under the AEZ 9 (Old Brahrnaputra Floodplain). The land was moderately well drained and soil was silt loam in texture.

\subsection{Rice crop, as a test materials}

BRRI dhan49, a high yielding variety of rice was test crop in this experiment. It is a high yielding rice variety, resistant to water logging developed by Bangladesh Rice Research Institute (BRRI), Joydebpur, Gazipur, and approved by National Seed Board (NSB) in 2008. Life cycle of this variety ranges from 132-135 days. It may vary due to climatic changes. Height of mature plants are 100-104 cm. The average grain yield of the variety generally lies between 5 to $5.5 \mathrm{t} \mathrm{ha}^{-1}$. This variety is somewhat resistant to pests and diseases especially stem rot, sheath blight and leaf blight.

\subsection{Layout of the experiment}

The experiment was laid out in a Randomized Complete Block Design (RCBD), where the experimental area was divided into 3 blocks representing the replications to reduce soil heterogenetic effects. Each block was divided into 8 unit plots with raised dyke treatments. Thus the total number of unit plots were 24 . The unit plot size was $10 \mathrm{~m}^{2}$ and plots were separated from each other by dyke. Unit blocks were separated from each other by $30 \mathrm{~cm}$ ails. Treatments were randomly distributed within the blocks.

\subsection{Treatments}

There were 8 treatments out of which one was fully recommended dose of fertilizers. Only six included banana leaf litter and Potassium in different combination with $\mathrm{K}$ containing fertilizer having fixed quantity of nitrogen and phosphorus. There was also one control treatment in which no fertilizer was used. The treatment combinations used for the experiment were as follows:

$\mathrm{T}_{1}=$ Control (No fertilizer)

$\mathrm{T}_{2}=100 \%$ Recommended Fertilizer Dose

$\mathrm{T}_{3}=50 \% \mathrm{~K}$ from banana leaves $+50 \% \mathrm{~K}$ from MoP

$\mathrm{T}_{4}=60 \% \mathrm{~K}$ from banana leaves $+40 \% \mathrm{~K}$ from $\mathrm{MoP}$

$\mathrm{T}_{5}=70 \% \mathrm{~K}$ from banana leaves $+30 \% \mathrm{~K}$ from MoP

$\mathrm{T}_{6}=80 \% \mathrm{~K}$ from banana leaves+ $20 \% \mathrm{~K}$ from $\mathrm{MoP}$

$\mathrm{T}_{7}=90 \% \mathrm{~K}$ from banana leaves $+10 \% \mathrm{~K}$ from MoP

$\mathrm{T}_{8}=100 \% \mathrm{~K}$ from banana leaves

\subsection{Manures and Fertilizer aplication}

Air dried Banana leaves were incorporated @ $30 \mathrm{~kg} \mathrm{ha}^{-1}$ (equivalent $50 \% \mathrm{~K}$ ), $36 \mathrm{~kg} \mathrm{ha}^{-1}$ (equivalent $60 \% \mathrm{~K}$ ), $42 \mathrm{~kg} \mathrm{ha}$ (equivalent $70 \% \mathrm{~K}$ ) $48 \mathrm{~kg} \mathrm{ha}^{-1}$ (equivalent $80 \% \mathrm{~K}$ ), $\left.54 \mathrm{~kg} \mathrm{ha}^{-1} 90 \% \mathrm{~K}\right) 60 \mathrm{~kg} \mathrm{ha}^{-1}$ as per treatments at 15 days before transplanting of the rice seedlings. The banana leaves were mixed thoroughly with the soil. Recommended nitrogen @ $100 \mathrm{~kg} \mathrm{ha}^{-1}$ from urea was applied in three equal split as per treatment. The first dose of urea was applied at 15 days after transplanting. The remaining doses of urea were top dressed at 32 days (active tillering stage) and 56 days (panicle initiation stage) after transplanting. $\mathrm{P}, \mathrm{K}$ and S were applied @ 20,60, and $12 \mathrm{~kg} \mathrm{ha}^{-1}$ from triple superphosphate, muriate of potash, and gypsum respectively in all the plots except control as basal dose.

\subsection{Collection and procedure of recording data}

5 hills were randomly selected from each plot at maturity to record the yield contributing characters like plant height (cm), number of effective tillers hill ${ }^{-1}$, panicle length $(\mathrm{cm})$, number of filled grains panicle ${ }^{-1}$ and 1000-grain weight $(\mathrm{g})$. Grain and straw yields were recorded plot wise and expressed as sun dry basis.

\subsubsection{Plant height}

The plant height was measured from the ground level to the top of the panicle. From each plot, plants of 5 hills were measured and averaged.

\subsubsection{Panicle length}

Measurement was done from basal node of the rachis to apex of each panicle. Each observation was an average of 5 hills.

\subsubsection{Number of effective tillers hill-1}

Five hills were taken randomly from each plot and total number of tillers hill ${ }^{-1}$ was recorded. The number of effective tillers hill ${ }^{-1}$ was also recorded. 


\subsubsection{Filled grains panicle-1}

Five panicles were taken randomly and the filled grains panicle ${ }^{-1}$ were counted and averaged.

\subsubsection{0-grain weight}

1000-grains were taken from each plot and weighed in an electrical balance.

\subsubsection{Grain and straw yields}

Grain and straw yields were obtained from each plot and weighed carefully. The yields were expressed as t ha ${ }^{-1}$ on $14 \%$ moisture basis.

\subsection{Statistical analysis}

The collected data were analyzed statistically by F-test to examine the treatment effects and the mean differences were adjudged by Duncan's Multiple Range Test (DMRT) (Gomez and Gomez, 1984) and ranking was indicated by letters.

\section{Results and discussion}

\subsection{Plant height $(\mathbf{c m})$}

The plant height of BRRI dhan49 varied significantly in different treatments due to application of organic manure (banana plant leaves) and chemical fertilizers and the results have been presented in Figure 1. The plant height ranged from 77.10 to $85.55 \mathrm{~cm}$. The highest value of plant height of $85.55 \mathrm{~cm}$ was recorded in treatment $\mathrm{T}_{3}(50 \% \mathrm{~K}$ from banana plant leaves $+50 \% \mathrm{~K}$ from MoP) which was statistically identical to that observed in treatment $\mathrm{T}_{2}$ (Recommended Fertilizer Dose) and the value was 84.80 . Treatments $\mathrm{T}_{4}(60 \% \mathrm{~K}$ from banana leaves + $40 \% \mathrm{~K}$ from $\mathrm{MoP}), \mathrm{T}_{5}(70 \% \mathrm{~K}$ from banana leaves $+30 \% \mathrm{~K}$ from $\mathrm{MoP})$ and $\mathrm{T}_{6}$ showed statistically identical plant height and the value were $83.70,83.34$ and $82.35 \mathrm{~cm}$ respectively. The lowest plant height $(77.10 \mathrm{~cm})$ was observed in $\mathrm{T}_{1}$, (control). The results indicated that the combined effect of treatment $\mathrm{T}_{3}(50 \% \mathrm{~K}$ from banana leaves $+50 \% \mathrm{~K}$ from MoP) when incorporated was more pronounced in increasing the plant height of BRRI dhan49 as compared to application of other treatments. Babu et al. (2001) observed that the plant height was significantly influenced by the application of organic matter and chemical fertilizers. Application of potassium significantly increased plant height (Singh, et al., 1993 and Thakur et al., 1993).

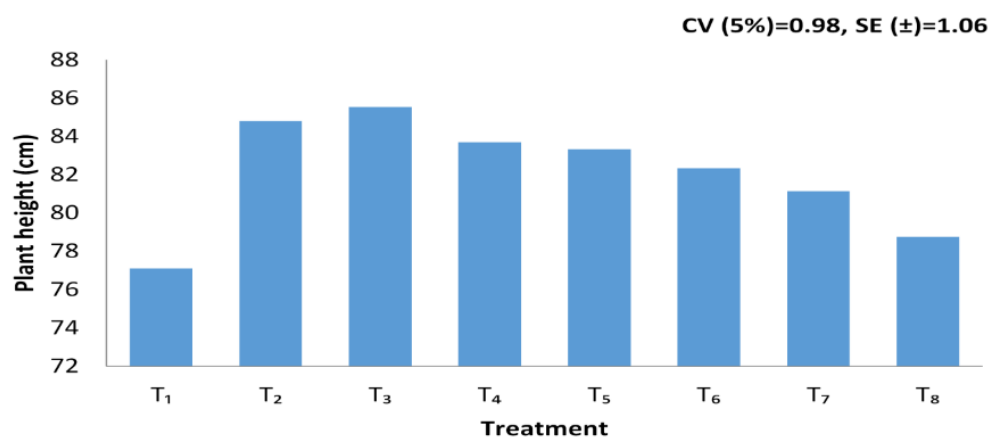

Fig. 1: Plant Height (Cm) Of BRRI Dhan49 as Influenced by Banana Leaves and Chemical Fertilizers.

\subsection{Number of effective tillers hill-1}

Number of effective tillers hill ${ }^{-1}$ were significantly varied among treatments which have been shown in Figure 2 . The number of effective tillers hill ${ }^{-1}$ ranged from 8.64 to 11.54 . The minimum number of effective tillers hill ${ }^{-1}$ was recorded in treatment $\mathrm{T}_{1}$ (control) and maximum in treatment $\mathrm{T}_{3}\left(50 \% \mathrm{~K}\right.$ from banana leaves $+50 \% \mathrm{~K}$ from MoP). The treatment $\mathrm{T}_{3}(50 \% \mathrm{~K}$ from banana leaves $+50 \% \mathrm{~K}$ from MoP) gave the highest number $(11.54 \%)$ of effective tillers hill ${ }^{-1}$ which was statistically identical to that observed in $\mathrm{T}_{2}$ (Recommended Fertilizer Dose) .Treatments $\mathrm{T}_{4}\left(60 \% \mathrm{~K}\right.$ from banana leaves $+40 \% \mathrm{~K}$ from MoP) and $\mathrm{T}_{5}(70 \% \mathrm{~K}$ from banana leaves $+40 \% \mathrm{~K}$ from MoP) produced statistically identical no. of effective tillers hill ${ }^{-1}$ and the values were 11.49 and 11.45 respectively. Treatment $\mathrm{T}_{3}$ gave the highest number $(11.54 \%)$ of effective tillers hill ${ }^{-1}$ which was statistically identical to that observed in $\mathrm{T}_{2}$ (Recommended Fertilizer Dose), and its value was 11.52 . Again $\mathrm{T}_{2}$ treatment showed statistically similar behavior to $\mathrm{T}_{4}$. The lowest number of tillers hill ${ }^{-1}$ (8.64) was recorded in $\mathrm{T}_{1}$ (control), which was significantly different from all other treatments.

It was observed that application of potassium increased of effective tillers hill-1 (Mahatim et al., 1979). Ahmed and Rahman (1991) reported that the combined application of organic matter and chemical fertilizer increased the tiller number of rice. Mondol et al. (1989) observed that the increasing rate of $\mathrm{K}_{2} \mathrm{O}$ from 40 to $160 \mathrm{~kg} \mathrm{ha}^{-1}$ increased the number of rice panicles $\mathrm{m}^{-2}$. Bhuiya and Akand (1982) also reported that the number of tillers at maximum growth stage was 16-21 due to application of organic materials (rice straw) and chemical fertilizer (NPK) combination. 
CV $(5 \%)=0.239$, SE $( \pm)=0.33$

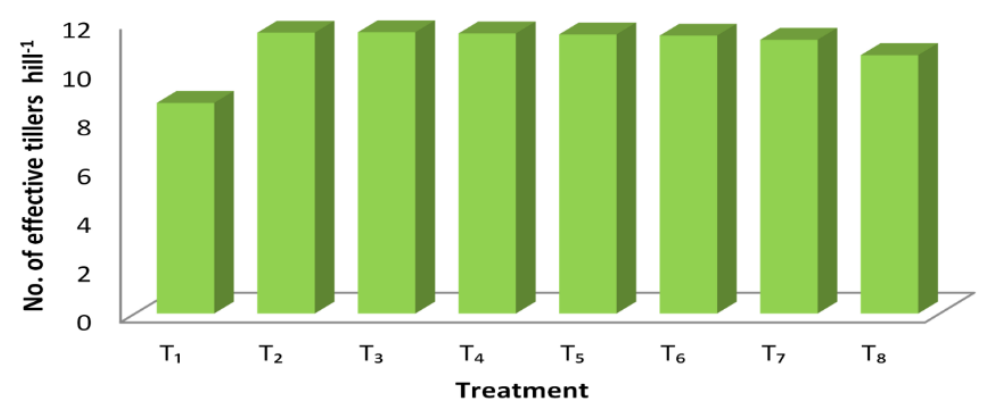

Fig. 2: Number of Effective Tillers Hill ${ }^{-1}$ Of BRRI Dhan49 as Influenced by Banana Leaves and Chemical Fertilizers.

\subsection{Panicle length}

Application of organic manures and chemical fertilizers showed significant effect on panicle length of rice (cv. BRRI dhan49). The panicle length ranged from 18.85 to $21.46 \mathrm{~cm}$ (Figure 3). The lowest panicle length was' found in treatment $\mathrm{T}_{1}$ (control). The highest value of $24.13 \mathrm{~cm}$ was found in treatment $\mathrm{T}_{3}(50 \% \mathrm{~K}$ from banana leaves $+50 \% \mathrm{~K}$ from MoP) which was statistically identical to panicle length found in treatment $\mathrm{T}_{2}$ (Recommended Fertilizer Dose). The results observed in treatments $\mathrm{T}_{4}(60 \% \mathrm{~K}$ from banana leaves $+40 \% \mathrm{~K}$ from $\mathrm{MoP})$ and $\mathrm{T}_{5}(70 \% \mathrm{~K}$ from banana leaves $+30 \% \mathrm{~K}$ from $\mathrm{MoP})$ were statistically identical. Treatment $\mathrm{T}_{5}$ and $\mathrm{T}_{6}$ are also identical. Umarah et al. (2003) noted that application of organic manure with chemical fertilizers increased the panicle length of rice. Ahmed and Rahman (1991) reported that application of organic matter and chemical fertilizers increased the panicle length of rice.

\section{CV $(5 \%)=0.064$, SE $( \pm)=2.86$}

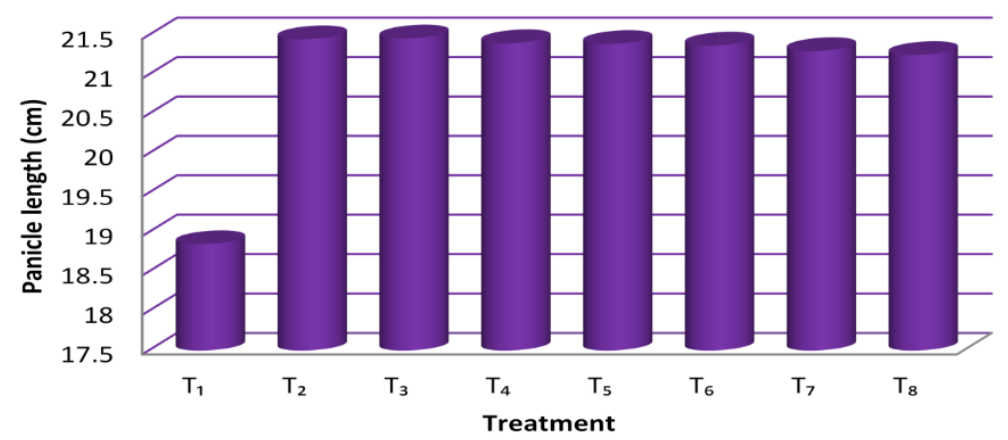

Fig. 3: Panicle Length (Cm) Of BRRI Dhan 49 as Influenced by Banana Leaves and Chemical Fertilizers.

\subsection{No. of filled grains panicle-1}

Results in Table 4.1 showed that the number of filled grains per panicle of rice (BRRI dhan49) was significantly affected due to various treatments. The number of filled grains per panicle varied from 112.11 to 149 (Figure 4). The highest no. of filled grains per panicle was found in treatment $\mathrm{T}_{3}(50 \% \mathrm{~K}$ from banana leaves $+50 \% \mathrm{~K}$ from MoP) $60 \% \mathrm{~K}$ from banana leaves $+40 \% \mathrm{~K}$ from MoP which was statistically identical to treatment $\mathrm{T}_{2}$ (Recommended fertilizer dose). Treatment $\mathrm{T}_{4}(60 \% \mathrm{~K}$ from banana leaves $+40 \% \mathrm{~K}$ from MoP) and treatment $\mathrm{T}_{5}(70 \% \mathrm{~K}$ from banana leaves $+30 \% \mathrm{~K}$ from $\mathrm{MoP})$ are statistically identical and value of them were 147.32 and 146.02 respectively. Treatment $\mathrm{T}_{2}$ (Recommended Fertilizer Dose) and $\mathrm{T}_{4}(60 \% \mathrm{~K}$ from banana leaves $+40 \% \mathrm{~K}$ from MoP) were statistically identical. The lowest no. of filled grains panicle ${ }^{-1}$ was found in $\mathrm{T}_{1}$, (control) and the value was 112.11 . This result is similar to the findings of Chang and Wong, 1962). It was reported that application of K increased the length of panicles (Mahatim et al., 1979, Thakur et al., 1993 and Haque, 1997). Shi et al. (1990) reported that application of K increase the number of filled grains panicle ${ }^{-1}$. Basal application of K showed positive effect on the percentage of filled grains (lsmunadji and Uexkull, 1974).

\section{$\mathrm{CV}(5 \%)=0.639, \mathrm{SE}( \pm)=4.2$}

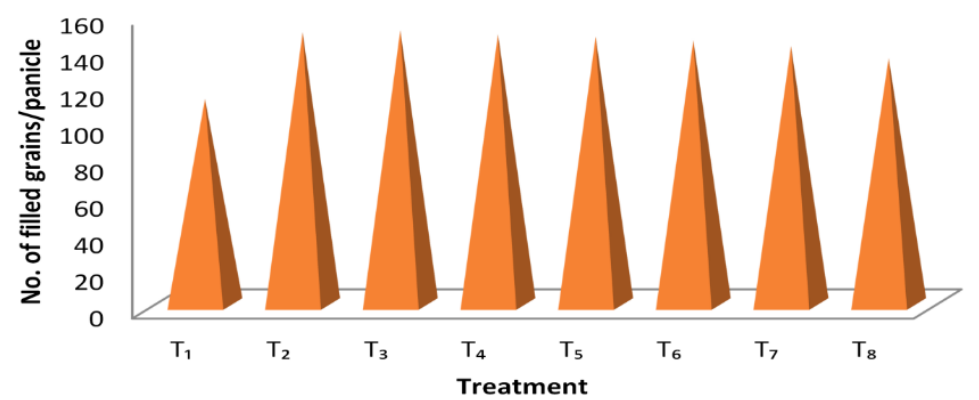

Fig. 4: No. of Filled Grains Panicle ${ }^{-1}$ of BRRI Dhan 49 as Influenced by Banana Leaves and Chemical Fertilizers.

\subsection{0-grain weight}


The results presented in the Table 4.1 showed that the weight of 1000 grain of rice (BRRI dhan49) was significantly affected by different treatments under the study. The 1000 grain weight ranged from 19.96 to $21.85 \mathrm{~g}$. The maximum weight of 1000 grain was found in treatment $\mathrm{T}_{3}\left(50 \% \mathrm{~K}\right.$ from banana leaves $+50 \% \mathrm{~K}$ from MoP) and minimum weight of 1000 grains was found in treatment $\mathrm{T}_{1}$ (control). The weight of 1000 grains in all the treatments was higher than that of treatment $\mathrm{T}_{1}$ (control). From the results it is clear that combined application of various organic and inorganic sources of potassium showed better performance in increasing 1000 grain weight over control (no fertilizer). Mitra et al. (2001) reported that application of K increased 1000 grain weight of rice. In an experiment, it was observed that the application of $\mathrm{K}$ increased 1000-grain weight (Mahatim et al., 1979). Talukder (1992) indicated from another study that 1000-grain weight increased with increasing K rate (Beltran et al., 1986, Mondal et al., 1989). It was also found that potassium has a positive effect and it tends to increase the 1000 grain weight (Ismunadji and Uexkull, 1974).

Table 1: 1000-Grain Weight (Gm) of BRRI Dhan49 as Influenced by Banana Leaves and Chemical Fertilizers

\begin{tabular}{ll}
\hline Treatment & 1000 grain weight $(\mathrm{gm})$ \\
\hline $\mathrm{T}_{1}$ & $19.96 \mathrm{f}$ \\
$\mathrm{T}_{2}$ & $21.75 \mathrm{ab}$ \\
$\mathrm{T}_{3}$ & $21.85 \mathrm{a}$ \\
$\mathrm{T}_{4}$ & $21.58 \mathrm{c}$ \\
$\mathrm{T}_{5}$ & $21.68 \mathrm{bc}$ \\
$\mathrm{T}_{6}$ & $21.13 \mathrm{~d}$ \\
$\mathrm{~T}_{7}$ & $20.24 \mathrm{e}$ \\
$\mathrm{T}_{8}$ & $20.15 \mathrm{e}$ \\
$\mathrm{CV}(\%)$ & 0.386 \\
$\mathrm{SE}( \pm)$ & 0.27 \\
\hline
\end{tabular}

The figure having common letter(s) in a column do not differ significantly at $5 \%$ level of significance by DMRT, SE $( \pm)=$ Standard error of means

\subsection{Grain yield}

The grain yield was significantly influenced due to different treatments (Table 2). The grain yield of rice (BRRI dhan49) ranged from 3.50 to 5.66 ton ha $^{-1}$. All the treatments produced significantly higher grain yield over control. The highest grain yield of 5.66 ton ha ${ }^{-1}$ was recorded in $\mathrm{T}_{3}\left(50 \% \mathrm{~K}\right.$ from banana leaves $+50 \% \mathrm{~K}$ from MoP) and the lowest yield 3.50 ton ha $^{-1}$ was recorded in treatment $\mathrm{T}_{1}$ (control). The results found in treatments $\mathrm{T}_{3}\left(50 \% \mathrm{~K}\right.$ from banana leaves $+50 \% \mathrm{~K}$ from MoP) and $\mathrm{T}_{2}$ (Recommended Fertilizer Dose) was statistically identical in replace of grain yield and the value were 5.66 and 5.64 ton ha ${ }^{-1}$ respectively. The highest percentage of increased grain yield over control $(61.71 \%)$ was recorded in the treatment $\mathrm{T}_{3}(50 \% \mathrm{~K}$ from banana leaves $+50 \% \mathrm{~K}$ from MoP). The lowest percentage of increased grain yield over control was found in $\mathrm{T}_{8}(100 \% \mathrm{~K}$ from banana leaves). This result is supported by Thakur and Patel (1998). This finding is also supported by Rahman et al. (2004); Rautray and Swain (2003). Abedin (2005) reported that incorporation of organic manure and chemical fertilizers in preceding crop significantly increased grain yield upto 52.22\% over control. Dwivedi and Thakur (2000) reported that grain yield was significantly increased due to application of organic manures and chemical fertilizers. Singh et al. (1999) found that application of potassium enhanced the grain yield of rice.

Table 2: Grain Yield (T/Ha) of BRRI Dhan49 as Influenced by Banana Leaves and Chemical Fertilizers

\begin{tabular}{lll}
\hline Treatment & Grain yield (t/ha) & Increase over control $(\%)$ \\
\hline $\mathrm{T}_{1}$ & $3.50 \mathrm{f}$ & - \\
$\mathrm{T}_{2}$ & $5.64 \mathrm{ab}$ & 61.14 \\
$\mathrm{~T}_{3}$ & $5.66 \mathrm{a}$ & 61.71 \\
$\mathrm{~T}_{4}$ & $5.63 \mathrm{bc}$ & 60.85 \\
$\mathrm{~T}_{5}$ & $5.62 \mathrm{~cd}$ & 60.57 \\
$\mathrm{~T}_{6}$ & $5.62 \mathrm{~cd}$ & 60.57 \\
$\mathrm{~T}_{7}$ & $5.60 \mathrm{~d}$ & 60 \\
$\mathrm{~T}_{8}$ & $4.85 \mathrm{e}$ & 38.57 \\
$\mathrm{CV}(\%)$ & 0.26 & - \\
$\mathrm{SE}( \pm)$ & 0.25 & - \\
\hline
\end{tabular}

The figure having common letter(s) in a column do not differ significantly at $5 \%$ level of significance by DMRT, SE $( \pm)=$ Standard error of means

\subsection{Straw yield}

Similar to the grain yield, straw yield of rice (BRRI dhan49) was significantly differed by different treatments and the results have shown in Table 3. All the treatments produced significantly higher yield of straw over control $\left(\mathrm{T}_{1}\right)$. The straw yield ranged from 4.73 to 6.81 ton ha ${ }^{-1}$. The maximum straw yield of 6.81 ton $\mathrm{ha}^{-1}$ was recorded in the treatment $\mathrm{T}_{3}(50 \% \mathrm{~K}$ from banana leaves $+50 \% \mathrm{~K}$ from MoP) and it was statistically identical to that found in the treatment $\mathrm{T}_{2}$ (Recommended Fertilizer Dose) with the value 6.76 ton ha $\mathrm{H}^{-1}$. The treatment $\mathrm{T}_{4}(60 \% \mathrm{~K}$ from banana leaves $+40 \% \mathrm{~K}$ from $\mathrm{MoP}$ ) produced 6.71 ton $\mathrm{ha}^{-1}$ straw which was also statistically identical with treatment $\mathrm{T}_{5}(70 \% \mathrm{~K}$ from banana leaves $+30 \% \mathrm{~K}$ from MoP). Treatments $\mathrm{T}_{6}\left(80 \% \mathrm{~K}\right.$ from banana leaves $+20 \% \mathrm{~K}$ from MoP) and $\mathrm{T}_{7}(90 \% \mathrm{~K}$ from banana leaves+ $10 \% \mathrm{~K}$ from MoP) are statistically similar and values were 6.64 and 6.61 ton $\mathrm{ha}^{-1}$ respectively. The lowest straw yield of 4.73 ton ha ${ }^{-1}$ was recorded in the treatment $\mathrm{T}_{1}$ (control). The highest percentage $(43.97 \%)$ of increased straw yield over control was found in $\mathrm{T}_{3}(50 \% \mathrm{~K}$ from banana leaves $+50 \% \mathrm{~K}$ from $\mathrm{MoP}$ ) and the lowest percentage $(25.79 \%)$ of increased straw yield over control was found in $\mathrm{T}_{8}(100 \% \mathrm{~K}$ from Banana leaves).Thus the results revealed that the straw yield of rice (BRRI dhan49) was markedly influenced by the application of organic manures and chemical fertilizer. Ahmed and Rahman (1991) reported that the application of organic manures and chemical fertilizers increased the straw yield of rice. Sahu (2001) pointed out that both grain and straw yields increased with addition of K. This result is supported by the finding of Mannan et al. (2000). Straw yields of BRRI dhan49 as influenced by banana plant leaves with MoP fertilizer was always higher than grain yields in all the treatments and has been shown in table 3 . 
Table 3: Straw Yield (T/Ha) of BRRI Dhan49 as Influenced by Banana Leaves and Chemical Fertilizers

\begin{tabular}{lll}
\hline Treatment & Straw yield $(\mathrm{t} / \mathrm{ha})$ & Increase over control $(\%)$ \\
\hline $\mathrm{T}_{1}$ & $4.73 \mathrm{f}$ & - \\
$\mathrm{T}_{2}$ & $6.76 \mathrm{ab}$ & 42.91 \\
$\mathrm{~T}_{3}$ & $6.81 \mathrm{a}$ & 43.97 \\
$\mathrm{~T}_{4}$ & $6.71 \mathrm{bc}$ & 41.86 \\
$\mathrm{~T}_{5}$ & $6.66 \mathrm{~cd}$ & 40.80 \\
$\mathrm{~T}_{6}$ & $6.64 \mathrm{~d}$ & 40.38 \\
$\mathrm{~T}_{7}$ & $6.61 \mathrm{~d}$ & 39.74 \\
$\mathrm{~T}_{8}$ & $5.95 \mathrm{e}$ & 25.79 \\
$\mathrm{CV}(\%)$ & 0.523 & - \\
$\mathrm{SE}( \pm)$ & 0.24 & - \\
\hline
\end{tabular}

The figure having common letter(s) in a column do not differ significantly at $5 \%$ level of significance by DMRT, SE $( \pm)=$ Standard error of means

\section{Conclusion}

It may be concluded from the results that the application of banana leaves with chemical fertilizers have a positive impact on the growth and yield contributing characters of rice. Among the treatments, $\mathrm{T}_{3}(50 \% \mathrm{~K}$ from banana leaves $+50 \% \mathrm{~K}$ from MoP) had a better performance on the grain and straw yields in comparison to chemical fertilizers alone. Therefore, banana leaves with inorganic fertilizer will be rewarding as supplement of organic source of potassium in rice cultivation. The present study also revealed that external use of potassium fertilizer could be reduced through use of banana leaves which will be economical.

\section{Acknowledgement}

Authors are grateful to the ministry of science and technology, Bangladesh for providing financial support to conduct the research work.

\section{Conflict of interest}

The authors have no conflict of interest to disclose.

\section{References}

[1] Abedin MJ (2005) Evaluation of acacia leaves and banana plant residues as supplement of potassium in rice cultivation M.S. Thesis in Soil Science, Bangladesh Agril. Univ. Mymensingh, p. 38-44.

[2] Ahmed M, Rahman S (1991) Influence of Organic Matter on the Yield and Mineral Nutrition of Modern Rich and Soil Properties. Bangladesh Rice J. 2(1), 107-112.

[3] Babu S, Marimuthu R, Manivannan V, Rameshkumar S (2001) Effect of organic and inorganic fertilizers on growth and yield of rice. Agril. Sci. Digest. 21(4), 232-234.

[4] Beltran R, Gonzalez W, Alive U, Miguel A, Copa N (1986) The effects of application of potassium fertilizer on yields of rice (Oyrza sativa) on Humic Gely Haydromorphic Soil. Ciencia-Y-Technica-EnLa-Agricultura, Suelos-Y-Agroquimica. 9(1), 7-13

[5] Bhuiya ZH, Akhand MS (1982) Effect of different sources of organic materials alone and in combination with two fertilizer levels on growth parameters and composition of rice. Bangladesh J. Agric. 7(3), 32-39.

[6] Dwivedi DK, Thakur SS (2000) Effect of organic and inorganic fertility levels on productivity of rice (Oryza sativa) crop. Indian J. Agron. 45(3), 568-574.

[7] Fageria NK, Wright RJ, Baligar VC, Carvalho JRP (1990) Upland rice response to potassium fertilization on a Brazilian oxisol. Fert Res. 21, 141-147. https://doi.org/10.1007/BF01087423.

[8] Gomez KA and Gomez AA (1984) Statistical Procedures for Agriculture Research. John Weley and Sons. Inc., New York. pp. 67-265.

[9] Haque MQ (1997) Potassium dynamics in major agro-ecological zones of Bangladesh in relation to the growth of rice and potato. Ph.D. Thesis. Department of Soil Science, University of Dhaka.

[10] Ismunadji M, Uexkull HRV (1974) Potassium responses of some padi soils in Java. Abstracts of papers. CLAMATROPS Conference on classification and management of tropical soils, Kualalampur Malaysia. 1977.

[11] Mahatim S, Singh RK,Singh M (1979) Split application of potassium in rice to maximize its utilization. India J Agron. 24(2), 193-198.

[12] Mannan MA, Kamal AMA, Islam MR (2000) Effect of Manure and Fertilizer on growth, yield and protein contain of transplant aman rice. Bangladesh J Training and Dev. 13(1), 203.210.

[13] Mitra GN, Shahoo D, Rout KK (2001) Effect of N-K interaction on yield, nutrient uptake and grain quality of rice-groundnut cropping sequence in the alluvial soils of Orissa. J. Potassium Res. 17(1), 71-78.

[14] Mondal SS, Jayaram D, Pradhan BK, Das SK (1989) Rate, time and pattern of application of nitrogen and potassium in influencing the yield components and yield of rice. J. Potassium Res. 5(2), 77-81.

[15] Mondal SS, Jayaram D, Pradhan BK, Das SK (1989) Rate, time and pattern of application of nitrogen and potassium in influencing the yield components and yield of rice. J. Potassium Res. 5(2), 77-81.

[16] Nambiar KKM (1991) Major Cropping System in India. In Agricultural sustainability: Economics environmental and statistical considerations (Eds. V. Barmett et al.,). John Wiley and Sons. Chichester, U.K. pp. 133-139.

[17] Sahu, SK (2001) Relationship between applied potassium and iron toxicity in rice. Intl. Rice Res. Notes. 26(2), 52-53.

[18] Shi QH, Zhong XH, Pan XH, Guo JY Zhang PL (1990) Studies on the characteristics of potassium absorption and yield of formation in early hybrid rice. Acta Agric. Univ., Jiangxiensis. 12(1), 54-59.

[19] Shymum N (2006) Integrated use of ash, water hyacinth and banana plant residues with inorganic potassium fertilizer in born rice cultivation (BRRI dhan 29). M.S. Thesis in Soil Science, Bangladesh Agril. Univ., Mymensingh, p. 26.

[20] Singh D, Singh V, Singh R (1999) Potassium status of soils and response of rice to applied potassium. Department of Agricultural Chemistry and Soil Science, RBS College, Uttar Pradesh, India. J. Potassium. Res. 13(1), 83-87.

[21] Singh J, Sharma HL, Singh CM (1993) Effect of levels and phases of potassium application on growth parameters of rice and wheat. Prof of the Inti. Symp and "A deuced of potassium research". Nov. 18-20. New Delhi, Indian, p. 129.

[22] Talukder RB (1992) Potassium fertilization in transplanted rice. J Potassium 8(2), 158-161. 
[23] Thakur DS, Patel SR (1998) Growth and sink potential of rice as influenced by the split application of potassium with FYM in Inceptisols of eastern central India. J. Potassium Res. 14(1-4), 73-77.

[24] Thakur RB, Jhan AK, Sharma RP (1993) Effect of levels and times of application of Potash on wetland rice. Proc. Intl. Symp. 18-20, June. New Delhi, India. p. 138.

[25] Thakur RB, Jhan AK, Sharma RP (1993) Effect of levels and times of application of Potash on wetland rice. Proc. Intl. Symp. 18-20, June. New Delhi, India. p. 138.

[1] Umarah EE, Expe EO, Ndon BA, Etim ME, Azbogu MS (2003) Effect of poultry manure on growth characteristics, yield and yield components of upland rice in South Eastern Nigeria. J. Sustain, Agric. Environ. 5(1), 105-110. 